\title{
A model to predict water intake of a pig growing in a known environment on a known diet
}

\author{
Stefano Schiavon ${ }^{1 *}$ and G. C. Emmans ${ }^{2}$ \\ ${ }^{1}$ Department of Animal Science, University of Padua, Agripolis, 35020 Legnaro (PD), Italy \\ ${ }_{2}^{2}$ Animal Biology Department, SAC, Bush Estate, Penicuik, Midlothian EH26 OQE, UK \\ (Received 11 October 1999 - Revised 21 March 2000 - Accepted 15 June 2000)
}

\begin{abstract}
A model to predict voluntary water intake (WI) of a pig fed a known diet in a known environment is described. The daily retentions of protein, lipid, water and ash were estimated over time using a published pig growth model. Food intakes were estimated using published methods. WI was estimated by adding the amounts required for digestion (WD), faecal excretion $\left(\mathrm{W}_{\mathrm{fec}}\right)$, growth (WG), evaporation (WE), urinary excretion (WU) and by then subtracting the water arising from feed (WF), from nutrient oxidation (WO) and synthesis of body constituents (WS). WD was predicted assuming an absorption of water of $0.10,0.16$ and $0.07 \mathrm{~kg} / \mathrm{kg}$ digestible carbohydrate, crude protein and lipid respectively. $\mathrm{W}_{\text {fec }}$ was estimated taking into account the water associated with the undigested protein $(0.86 \mathrm{~kg} / \mathrm{kg})$, diethyl ether extract $(-12.11 \mathrm{~kg} / \mathrm{kg})$, crude fibre $(1.86 \mathrm{~kg} / \mathrm{kg})$, ash $(-0.42 \mathrm{~kg} / \mathrm{kg})$ and $\mathrm{N}$-free extract $(4.4 \mathrm{~kg} / \mathrm{kg})$. The basal level of WE was estimated from the heat production of the pig fed ad libitum $(\mathrm{MJ} / \mathrm{d})$ as: $0.25 \times$ (metabolizable energy - energy retained as protein and lipid) $\times 0.4$, where 0.25 is the assumed proportion of the insensible heat loss at the comfort temperature and 0.4 is the water lost per MJ dissipated heat. WE in a hot environment was predicted by assuming that evaporation increased up to three times the basal level to offset the decreased sensible heat loss. To predict WU a water requirement for renal excretion of 2.05 and $3.40 \mathrm{~kg} / \mathrm{osmol}$ excreted $\mathrm{N}$ as urea and minerals respectively was assumed. The urinary load of $\mathrm{N}$ and minerals was predicted from the intake of digestible nutrients and their retention. From the oxidation of $1 \mathrm{~kg}$ carbohydrate, protein, and fat it was assumed that $0.6,0.42$ and $1.07 \mathrm{~kg}$ water (WO) were released respectively. WS was predicted by assuming a release of $0 \cdot 16,0.07$ and $0.57 \mathrm{~kg}$ water per $\mathrm{kg}$ retained protein, retained lipid coming from digestible lipid, and retained lipid coming from digestible carbohydrate respectively. The model is strongly rooted in a theoretical structure. When its predictions were compared with data from suitable experiments, the results were not significantly different. Both the pattern and the magnitude of responses of the model to changes in body weight, feed intake and environmental temperature are sensible and it allows a fuller prediction of voluntary water intake than the methods currently available.
\end{abstract}

\section{Water: Mathematical model: Pig}

Several models have been proposed to predict potential pig performance in non-limiting conditions (e.g. Black, 1995; Schinckel, 1999) but of these, few predict intake. Energy and nutrient intake and retention are predicted on a daily basis from birth to maturity using a very limited number of inputs to describe the animal genotype, the feed and the environment by the model of Ferguson et al. 1994 (see also Emmans, 1988, 1997). This model allows the flow of nutrients from a pig to be predicted by calculating the difference between daily intake and daily retention of nutrients (Aarnink et al. 1992).

None of the numerous models contains, however, a prediction of the voluntary water intake, nor any quantitative description of the water lost by evaporation or excreted in the faeces and the urine. The Agricultural Research Council (1981) suggests a voluntary water intake for growing pigs ranging from about 2 to $5 \mathrm{~kg} / \mathrm{kg}$ feed. Results of many experiments (Agricultural Research

\footnotetext{
Abbreviations: WD, water demand for the digestive hydrolysis of nutrients; WE, water demand for evaporation; $\mathrm{WF}$, water gained from feed; $\mathrm{W}_{\text {fec }}$, water demand for faecal excretion; WG, water stored in the body tissues; WI, water intake; WO, water gained from oxidation; WS, water arising from protein and lipid synthesis; WU, water demand for urine excretion.

* Corresponding author: Dr Stefano Schiavon, fax + 3949 8272633, email sschiavo@agripolis.unipd.it
} 
Council, 1981; National Research Council, 1988) indicate how this ratio can vary substantially according to several factors such as environmental temperature, the protein and mineral content of the diet, body weight and health status.

In many European countries, water is increasingly becoming an important resource. Water use in animal husbandry is regulated by laws concerned with animal welfare, and the environmental impact of slurry disposal. As a consequence it is important to try to estimate more precisely the amount of water needed by the pig as an inadequate water provision may also have deleterious effects on animal performance.

As many factors influence the water requirement we have chosen to examine the theoretical effects of each of several factors in a model simulating the animal water metabolism. In this present paper, a first model to predict water intake of a growing pig is proposed.

\section{Definition of the system boundaries}

Following a factorial approach, voluntary water intake can be considered to be influenced by the variable amounts of water required to meet several physiological functions: digestion of nutrients, faecal excretion, growth, evaporation, osmotic regulation and urinary excretion of the end products of protein catabolism, salts, drugs, toxic compounds and antibiotics. Water demand can be greatly affected by water quality (Brooks \& Carpenter, 1990) and acid-base balance (Kemme-Kroonsberg, 1993; Patience \& Chaplin, 1997). Non-physiological factors can also affect water consumption. Among these are: the type and the number of drinkers available in the pen and the water delivery rate (Brooks \& Carpenter, 1990; Laitat et al. 1999; Turner et al. 1999); the presence of diuretic or antidiuretic substances in the diet, such as some antibiotics (Brooks \& Carpenter, 1990); the health status of the animal and anomalous behaviours such as polydypsia (Appleby \& Lawrence, 1987; Klopfenstein et al. 1996). All these factors, however, can be considered as deviations from the theoretical ideal working conditions of the pig's basal physiology.

Voluntary water intake has been shown to be stimulated by both a rise in extracellular osmolality and a fall in blood volume (Fitzsimons, 1979), but Houpt \& Anderson (1990) failed to find any evidence of an action of hypertonicity and hypovolaemia in stimulating drinking in pigs given food and water ad libitum. The effects of these mechanisms are likely to operate only when the pig is forced to eat, in a single meal, a large amount of food. Under ordinary feeding conditions it can be assumed that the pig drinks in order to replace the amounts of water lost and stored in the body tissues. A basal model to predict the voluntary water intake can be developed by considering, in the first instance, the following simplified system: (1) the pig is fed a known diet under ordinary feeding regimens (feed is not strongly restricted); (2) the environmental temperature is known; (3) the animal has free access to a free surface of pure water; (4) no drugs, antibiotics or other diuretic or antidiuretic substances are given to the animal; (5) the animal is in good health and no anomalous behaviours are observed.

On the basis of these assumptions water demand for each physiological function can be related to some of the several steps of the process of nutrient utilization as shown in Fig. 1 and water intake (WI) can be predicted as:

$$
\begin{aligned}
\mathrm{WI}(\mathrm{kg} / \mathrm{d})= & \mathrm{WD}+\mathrm{W}_{\mathrm{fec}}+\mathrm{WE}+\mathrm{WG}+\mathrm{WU}-(\mathrm{WF} \\
& +\mathrm{WO}+\mathrm{WS}),
\end{aligned}
$$

where WD is the water demand for digestion $(\mathrm{kg} / \mathrm{d}), \mathrm{W}_{\mathrm{fec}}$ is the water demand for faecal excretion $(\mathrm{kg} / \mathrm{d})$, WE is the water demand for evaporation $(\mathrm{kg} / \mathrm{d})$, WG is the water stored in the body tissues $(\mathrm{kg} / \mathrm{d})$, WU is the water demand for urine excretion $(\mathrm{kg} / \mathrm{d})$, WF is the water gained from feed $(\mathrm{kg} / \mathrm{d})$, WO is the water arising from the oxidation of nutrients $(\mathrm{kg} / \mathrm{d})$ and WS is the water arising from the protein and lipid synthesis $(\mathrm{kg} / \mathrm{d})$.

\section{Definition of the model components}

\section{Growth of body constituents and prediction of nutrient excretion}

The prediction of the growth of each of the body constituents (protein, lipid, water and ash), and of the whole pig, is the necessary first step in order to estimate the excretion of chemical elements and compounds and water flows through the animal. To this purpose the general growth model for mammals of Emmans (1988, 1997), and of Ferguson et al. (1994) for pigs, has been adopted with few changes. In the present model feeds are firstly described in terms of their proximate composition, and their contents of amino acids and minerals $(\mathrm{Ca}, \mathrm{P}, \mathrm{Na}, \mathrm{Cl}$, $\mathrm{K}, \mathrm{Mg}$ and $\mathrm{S}$ ). Apparent digestibility coefficients are required as inputs to apply the model and faecal excretions are measured as the difference between the proximate and the digestible intakes. Similarly, the urinary excretions of N and minerals are obtained as the difference between the digestible nutrient intake and the retention. $\mathrm{N}$ is contained in different urinary compounds (urea, $\mathrm{NH}_{3}$, creatinine and allantoin), but since urea represents a predominant proportion of the total $\mathrm{N}$ excretion, it can be assumed, at least in this first instance, that it is completely excreted as urea. The supply of minerals is assumed not to be limiting. The original growth model of Ferguson et al. (1994) predicts daily ash retention but not its composition. From published data obtained on pigs at different ages at slaughter (Mahan \& Shields, 1998), the proportions of $\mathrm{Ca}, \mathrm{P}, \mathrm{Na}, \mathrm{K}$ and $\mathrm{Mg}$ were calculated to be $293,184,27,34$ and $7 \mathrm{~g} / \mathrm{kg}$ ash respectively. From the data of Mudd et al. (1969) it was assumed that the $\mathrm{Cl}$ content of ash is about $0 \cdot 8$ that of $\mathrm{Na}$ $(21.5 \mathrm{~g} / \mathrm{kg})$. Differences in the amount or composition of body ash are expected to have a very little effect on the urinary excretion of water so these proportions are assumed to be constant during growth. Retention of $\mathrm{S}$ is related to the proportion of methionine and cystine in the retained protein, since they contain 21.4 and $26.4 \% \mathrm{~S}$ respectively (Blaxter, 1989).

\section{Water gained from the feed}

A pig eating a given diet is obliged to 'drink' the water contained in the feed. The amount of water consumed in this way is the product of feed consumption and its 
Inputs

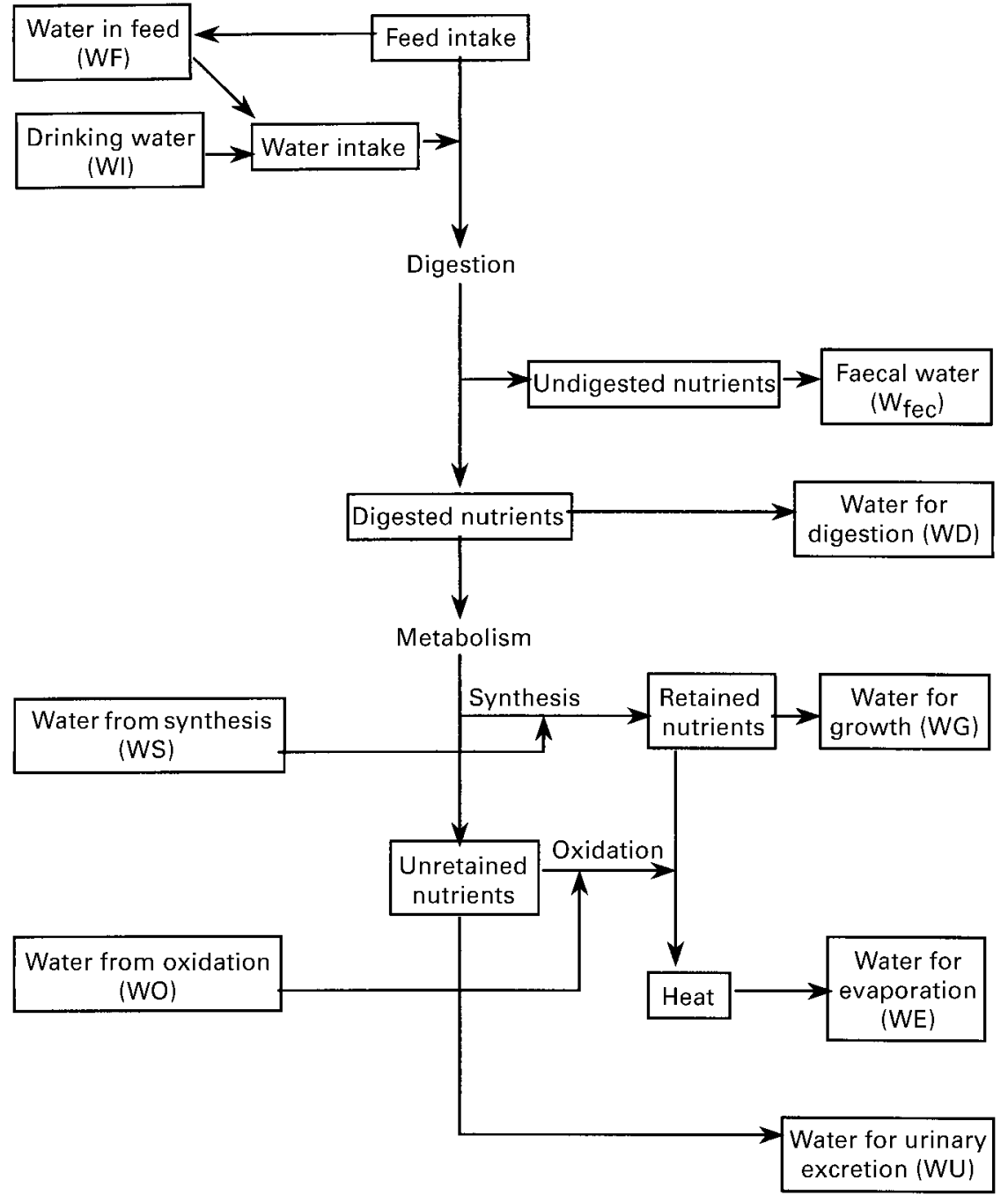

Fig. 1. Inputs and outputs of water with regard to nutrient utilization.

moisture content. The proportion of water gained from the feed is small in the case of dry diets, such as those based on cereals and soyabean meal. However, the contribution of feed water to water supply may be considerable when the diet includes high moisture feeds. Liquid by-products such as skimmed milk, whey, brewery washings, the residues from starch manufacture, ensiled products and grass or roots are regularly used in some regions to feed pigs, depending on their cost and local availability. Water consumption with feeds can be very high in the case of diets distributed to the animals through pipelines in liquid form. Since the normal proportion of water to feed intake is in the range of $2 \cdot 5: 1$ and $5 \cdot 0: 1$, the water gained by this route could be sometimes higher than the desired WI. In this case the model assumes that the animal will reduce voluntary water intake to zero, and that the excess water is removed through the urine.

\section{Water demand for digestion}

The model makes the simplified assumption that during digestion polysaccharides, protein and triacylglycerol are hydrolysed to monosaccharides, amino acids, fatty acids and glycerol before being absorbed through the intestinal wall. The hydrolytic reaction requires $1 \mathrm{~mol}$ water for each mol simple nutrient released. Water requirement for the digestion of carbohydrate can be approximately assessed by dividing the mass of digested carbohydrate by the average relative molecular mass of their main constituent monosaccharide (glucose) and multiplying it by the relative molecular mass of water. For the purpose of this model the digestible $\mathrm{N}$-free extract was assumed to be equivalent to digestible carbohydrate. A similar stoichiometric approach can be adopted to calculate the water requirements for the digested protein and lipid. Thus, water requirement for the digestion of the dietary constituents can be estimated as:

$$
\begin{aligned}
\mathrm{WD}(\mathrm{kg} / \mathrm{d})= & (18 / 162) \mathrm{DCHO}+(18 / 110) \mathrm{DCP} \\
& +(18 / 268) \mathrm{DL} .
\end{aligned}
$$


Table 1. Proximate composition $(\mathrm{g} / \mathrm{kg})$ of 150 faecal grab samples collected in twelve Latin square trials with eight miniature pigs fed twenty-three different diets ${ }^{*}$

(Mean values, standard deviations and ranges)

\begin{tabular}{lrcc}
\hline Proximate component & Mean & SD & Range \\
\hline Water & 641 & 66 & $473-809$ \\
Crude protein & 56 & 16 & $16-105$ \\
Diethyl ether extract & 12 & 4 & $3-25$ \\
Crude fibre & 59 & 20 & $18-127$ \\
Ash & 88 & 36 & $24-252$ \\
N-free extract & 144 & 25 & $72-205$ \\
\hline
\end{tabular}

* G Bittante, S Schiavon and L Bailoni, unpublished results.

This is equivalent to:

$$
\mathrm{WD}(\mathrm{kg} / \mathrm{d})=0 \cdot 11 \mathrm{DCHO}+0 \cdot 16 \mathrm{DCP}+0 \cdot 07 \mathrm{DL},
$$

where DCHO is the digested carbohydrate $(\mathrm{kg} / \mathrm{d})$, DCP is the digested protein $(\mathrm{kg} / \mathrm{d}), \mathrm{DL}$ is the digested lipid $(\mathrm{kg} / \mathrm{d})$; 18 is the relative molecular mass of water, 162 is the relative molecular mass of glucose -1 mol water; 110 is the assumed average relative molecular mass of amino acid $-1 \mathrm{~mol}$ water, 268 is the assumed average relative molecular mass of fatty acid $+1 / 3$ relative molecular mass of glycerol -3 mol water. The assumed average relative molecular mass of fatty acid is that of the palmitic acid.

\section{Water demand for faecal excretion}

According to Brooks \& Carpenter (1990) $\mathrm{W}_{\text {fec }}$ is assumed to depend on the amount of water retained by each faecal constituent. Important connections between the fibrous components and the water contents of the faeces have been demonstrated for pigs by Cooper \& Tyler $(1959 a, b)$ and for human subjects by Forsum et al. (1990). However, no useful data have been as yet published to evaluate the amount of water held by each faecal component.

For a preliminary evaluation, a data set (Table 1) of 150 faecal grab samples collected in the research station of the University of Padua, Italy, from eight miniature pigs eating twenty-three different feeds in twelve consecutive digestion trials (G Bittante, S Schiavon and L Bailoni, unpublished results) has been used. The pigs were fed at maintenance; according to the results of Kornegay \& Graber (1968), the level of feed intake was not considered to affect faecal moisture content. In this data set only the proximate analysis was known and so the amounts of water associated with the various fibrous fractions were not evaluated. The following equation has been evaluated by running a multiple regression analysis of the data set:

$$
\begin{aligned}
\mathrm{W}_{\text {fec }}(\mathrm{g} / \mathrm{kg} \text { fresh faeces })= & \mathrm{aCP}_{\text {fec }}+\mathrm{bCEE}_{\text {fec }}+\mathrm{cCF}_{\text {fec }} \\
& +\mathrm{dASH}_{\text {fec }}+\mathrm{eNFE}_{\text {fec }},
\end{aligned}
$$

where $\mathrm{CP}_{\text {fec }}$ is the faecal crude protein $(\mathrm{g} / \mathrm{kg}), \mathrm{CEE}_{\text {fec }}$ is the faecal diethyl ether extract $(\mathrm{g} / \mathrm{kg}), \mathrm{CF}_{\mathrm{fec}}$ is the faecal crude fibre $(\mathrm{g} / \mathrm{kg}), \mathrm{ASH}_{\text {fec }}$ is the faecal ash $(\mathrm{g} / \mathrm{kg}), \mathrm{NFE}_{\text {fec }}$ is the faecal $\mathrm{N}$-free extract $(\mathrm{g} / \mathrm{kg})$ and $\mathrm{a}, \mathrm{b}, \mathrm{c}, \mathrm{d}$ and e are
Table 2. Amounts of water associated with each faecal compound in pig faeces ${ }^{\star} t$

(Mean values with their standard errors for 150 samples)

\begin{tabular}{lccc}
\hline & \multicolumn{2}{c}{ Water (g/kg undigested nutrient) } & \\
\cline { 2 - 3 } & Mean & SE & $P$ \\
\hline Crude protein & 860 & 1607 & 0.594 \\
Diethyl ether extract & -12108 & 4769 & 0.012 \\
Crude fibre & 1865 & 728 & 0.011 \\
Ash & -423 & 692 & 0.542 \\
N-free extract & 4440 & 687 & 0.001 \\
\hline * G Bittante, S Schiavon and L Bailoni, unpublished results. & \\
$\dagger+$ Overall equation $P<0.001$, residual SD 157 g/kg, $R^{2} 0.94$. &
\end{tabular}

coefficients measuring respectively the amount of water associated with each chemical compound.

Results, given in Table 2 (G Bittante, S Schiavon and L Bailoni, unpublished results), showed that crude protein, crude fibre and $\mathrm{N}$-free extract were associated with about 860,1865 and $4440 \mathrm{~g}$ water $/ \mathrm{kg}$ undigested nutrient respectively. Diethyl ether extract significantly decreased faecal moisture $(-12108 \mathrm{~g} / \mathrm{kg})$, probably because of its hydrophobic characteristics.

With an adequate data set the equation could be improved by replacing crude fibre and $\mathrm{N}$-free extract with the various carbohydrates fractions (i.e. cellulose, hemicellulose, pentosanes, pectins, gums and lignin) which greatly differ in their physical properties (Graham \& Aman, 1991). The physical structure of the feed source should be also taken into account (Robertson \& Eastwood, 1981).

\section{Water demand for growth}

According to Emmans (1988) and Emmans \& Kiriazakis (1997) the relationship between body protein and water can be described as:

$$
\mathrm{BW}(\mathrm{kg})=\mathrm{aP}^{\mathrm{b}},
$$

where BW is the body water content $(\mathrm{kg})$, a is a coefficient which depends on mature protein weight, $\mathrm{P}$ is the body protein $(\mathrm{kg})$ and $\mathrm{b}$ is the allometric coefficient which is estimated for pigs to be close to 0.855 (Emmans \& Kiriazakis, 1997).

The equations can be used to derive water retention with regard to protein retention $(\mathrm{dBW} / \mathrm{dP})$ as:

$$
\mathrm{dBW} / \mathrm{dP}=\mathrm{a} \times \mathrm{b} \times \mathrm{P}^{(\mathrm{b}-1)} \text {. }
$$

The daily amount of water stored during growth is then obtained from:

$$
\mathrm{WG}(\mathrm{kg} / \mathrm{d})=\mathrm{dBW} / \mathrm{dt}=(\mathrm{dBW} / \mathrm{dP}) \times \mathrm{dP} / \mathrm{dt},
$$

where $\mathrm{dP} / \mathrm{dt}$ is the daily protein retention $(\mathrm{PR})$, obtained as described by Emmans \& Fisher (1986).

\section{Water arising from the synthesis of body protein and lipid}

When amino acids, carbohydrates, fatty acids and glycerol are bound again to form macromolecules WS is proportional to the amount of protein and lipid retained and to the chemical nature of the source used. To estimate WS, a 
prediction of the metabolic fate of the absorbed nutrients is required. To this purpose, and on the basis of the results of Emmans (1994), the following assumptions were made: (1) the digested protein that is not retained (DCP-PR) is completely oxidized; (2) digested lipid (DL) is retained with an efficiency of 0.9 so that its contribution to lipid retention (LR) can be evaluated as:

$$
\mathrm{LR}_{(\mathrm{DL})}(\mathrm{kg} / \mathrm{d})=0 \cdot 9 \mathrm{DL}
$$

Then the lipid retention from carbohydrates is calculated as:

$$
\mathrm{LR}_{\left(\mathrm{DCHO}_{\mathrm{s}}\right)}(\mathrm{kg} / \mathrm{d})=\mathrm{LR}-\mathrm{LR}_{(\mathrm{DL})},
$$

where LR is obtained as described by Emmans (1997).

It is assumed that 0.16 and $0.07 \mathrm{~g}$ water are released for each $g$ PR and $L_{(D L)}$ respectively. Water arising from the metabolic conversion of carbohydrate to lipid is calculated on the basis that the synthesis of 3 mol palmitic acid from glucose is associated with release of 24 mol water (Blaxter, 1989). Another 3 mol water are gained when fatty acids and glycerol are bound together in triacylglycerol (relative molecular mass 806). A lipid retention of $806 \mathrm{~g}$ (3 mol palmitic acid and $1 \mathrm{~mol}$ glycerol) is associated with a release of water of $486 \mathrm{~g}(27 \mathrm{~mol})$ that, in relative terms, is $0.60 \mathrm{~g}$ water/g retained lipid. So WS can be estimated as:

$$
\mathrm{WS}(\mathrm{kg} / \mathrm{d})=0 \cdot 16 \mathrm{PR}+0 \cdot 07 \mathrm{LR}_{(\mathrm{DL})}+0 \cdot 60 \mathrm{LR}_{\left(\mathrm{DCHO}_{\mathrm{s}}\right)} .
$$

\section{Water arising from nutrient oxidation}

Metabolic water arising from the oxidation of carbohydrates, protein and lipid can be derived from the stoichiometry of the respective reactions. The oxidation of $1 \mathrm{~kg}$ carbohydrate, protein and lipid produces $0.60,0.42$ and $1.07 \mathrm{~kg}$ water respectively (Van Es, 1969); similar values were reported by National Research Council (1998). The proposed equation is:

$$
\mathrm{WO}(\mathrm{kg} / \mathrm{d})=0 \cdot 42 \mathrm{POX}+1 \cdot 07 \mathrm{LOX}+0 \cdot 60 \mathrm{DCHOOX},
$$

where POX is the oxidized protein $(\mathrm{kg} / \mathrm{d})$, calculated as DCP - PR, LOX is the oxidized lipid $(\mathrm{kg} / \mathrm{d})$, obtained as DL - LR(DL), DCHOOX is the oxidized carbohydrates $(\mathrm{kg} / \mathrm{d})$, obtained as a difference between the digestible carbohydrates (DCHO) and the amounts used to form lipid $\left(\mathrm{DCHO}_{\mathrm{S}}\right)$. In turn, $\mathrm{DCHO}_{\mathrm{S}}$ is computed assuming that $2 \cdot 81$ and $0.98 \mathrm{~g}$ glucose are required to form $1 \mathrm{~g}$ palmitic acid and $1 \mathrm{~g}$ glycerol respectively (Blaxter, 1989), and that the proportions of glycerol and palmitic acid in the synthesized lipid are 0.11 and $0 \cdot 89$. Thus, the amount of carbohydrate used for lipid synthesis can be obtained as:

$$
\begin{aligned}
\operatorname{DCHO}_{\mathrm{S}}(\mathrm{kg} / \mathrm{d})= & 0 \cdot 89 \mathrm{LR}_{\left(\mathrm{DCHO}_{\mathrm{S}}\right)} 2 \cdot 81 \\
& +0 \cdot 11 \mathrm{LR}_{\left(\mathrm{DCHO}_{\mathrm{S}}\right)} 0 \cdot 98 .
\end{aligned}
$$

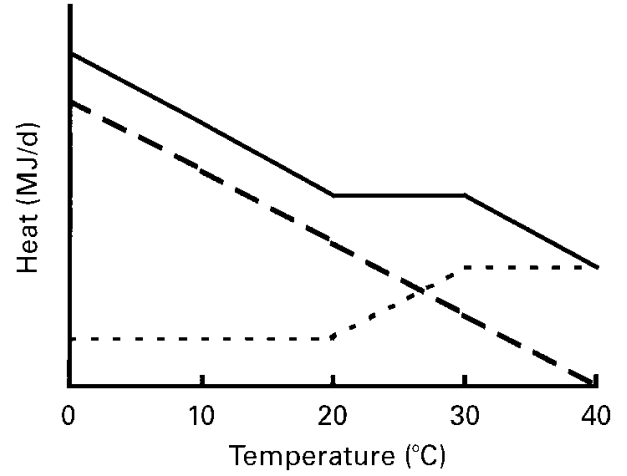

Fig. 2. Partition of heat production into sensible (non-evaporative) and insensible losses per unit of surface area. —-, heat production; - -, sensible heat losses; - - - -, insensible heat losses. (Modified from Blaxter, 1989.)

This can be simplified to:

$$
\mathrm{DCHO}_{\mathrm{S}}(\mathrm{kg} / \mathrm{d})=2 \cdot 60 \mathrm{LR}_{\left(\mathrm{DCHO}_{\mathrm{S}}\right)} .
$$

\section{Water demand for evaporation}

Heat partition between sensible (SHL) and insensible (IHL) heat losses of mammals, according to different environmental temperatures, was graphically described by Robertshaw (1981), Blaxter (1989) and Knap (1999). A simplified scheme is given in Fig. 2. The energy cost of cold thermogenesis (b) is about $0 \cdot 018 \mathrm{MJ} \mathrm{ME} /{ }^{\circ} \mathrm{C}$ per unit metabolic body weight for pigs housed singly, and 0.012 MJ for pigs housed in groups (Whittemore, 1993). Using these values the environmental demand of sensible heat (SHLd) can be approximately described by the linear function:

$$
\operatorname{SHLd}(\mathrm{MJ} / \mathrm{d})=\left(\mathrm{a}-\mathrm{bT}^{\circ}\right) \mathrm{LW}^{0.75},
$$

where $\mathrm{T}^{\circ}$ is the environmental temperature, $\mathrm{LW}^{0.75}$ is the metabolic weight and $\mathrm{a}$ is a value ranging from 0.72 / $\mathrm{LW}^{0.75}$ to $0.48 / \mathrm{LW}^{0.75}\left(\mathrm{MJ} / \mathrm{kg}^{0.75}\right)$, according to the value of $\mathrm{b}$, since SHL tends to be zero at about $40^{\circ} \mathrm{C}$.

For a pig fed ad libitum in a thermally neutral environment, total heat production $\left(\mathrm{HP}_{\mathrm{lib}}\right)$ is predicted as the difference between the desired metabolizable energy intake $\left(\mathrm{ME}_{\mathrm{lib}}\right)$ and the desired energy retention $\left(\mathrm{ER}_{\mathrm{lib}}\right)$ (Emmans \& Fisher, 1986). In the pig eating spontaneously, the basal level of the insensible heat loss at thermoneutrality $\left(\mathrm{IHL}_{\mathrm{lib}}\right.$ ) accounts for approximately 20-30\% total heat production (Mitchell \& Kelly, 1938; Holmes \& Mount, 1967; Close \& Mount, 1978). On this basis, the partition of heat production is predicted as:

$$
\begin{gathered}
\mathrm{HP}_{\mathrm{lib}}(\mathrm{MJ} / \mathrm{d})=\mathrm{ME}_{\mathrm{lib}}-\mathrm{ER}_{\mathrm{lib}}, \\
\mathrm{IHL}_{\mathrm{lib}}(\mathrm{MJ} / \mathrm{d})=0.25 \mathrm{HP}_{\mathrm{lib}},
\end{gathered}
$$

and

$$
\mathrm{SHL}_{\mathrm{lib}}(\mathrm{MJ} / \mathrm{d})=0 \cdot 75 \mathrm{HP}_{\text {lib }} \text {. }
$$

For a pig fed a restricted diet heat production (HP) is 
lower than $\mathrm{HP}_{\text {lib }}$ and, consequently, the critical temperature will be higher than that of the pig fed ad libitum. Nevertheless, the results of Blaxter et al. (1959) and Close \& Mount (1978) indicate that the amount of heat lost by evaporation (IHL) below the critical temperature can be considered the same as that of the animal fed ad libitum. The comfort temperature (Tc) of a pig receiving a restricted diet is that where the environmental demand for sensible heat (SHLd) is met by the amount of heat the pig will dissipate by the sensible route without needing to increase evaporation, or when SHL $=\mathrm{HP}-\mathrm{IHL}_{\mathrm{lib}}$. Thus, Tc can be predicted by replacing SHLd of equation 14 by SHL (i.e. $\mathrm{HP}-\mathrm{IHL}_{\mathrm{lib}}$ ) and transforming to obtain:

$$
\mathrm{Tc}\left({ }^{\circ} \mathrm{C}\right)=\left(\mathrm{SHL}-\left(\mathrm{a} \times \mathrm{LW}^{0.75}\right)\right) /\left(-\mathrm{b} \times \mathrm{LW}^{0.75}\right) .
$$

If:

$$
\mathrm{T}^{\circ} \leq \mathrm{Tc}
$$

then:

$$
\mathrm{IHL}=\mathrm{IHL}_{\mathrm{lib}} \cdot
$$

When $\mathrm{T}^{\circ}>\mathrm{Tc}$, evaporation necessarily becomes a major avenue of heat loss, since non-evaporative or sensible heat loss is progressively reduced to zero. Various experimental results, reviewed by Knap (1999), suggest that the pig is able to offset the decrease in sensible heat loss by doubling the skin loss and tripling the lung loss. According to Knap (1999), it is assumed that the pig can increase, by up to three times, the basal level of $\mathrm{IHL}_{\mathrm{lib}}$. Thus IHL can be estimated as:

$$
\operatorname{IHL}(\mathrm{kg} / \mathrm{d})=\mathrm{IHL}_{\mathrm{lib}}+\mathrm{b}\left(\mathrm{T}^{\circ}-\mathrm{Tc}\right) \mathrm{LW}^{0 \cdot 75} .
$$

If:

$$
\mathrm{IHL}>3 \mathrm{IHL}_{\mathrm{lib}}
$$

then:

$$
\operatorname{IHL}(\mathrm{kg} / \mathrm{d})=3 \mathrm{IHL}_{\mathrm{lib}} \text {. }
$$

In this case, the maximum amount of heat that the pig is able to dissipate to the environment is:

$$
\mathrm{HP}_{\mathrm{d}}(\mathrm{MJ} / \mathrm{d})=3 \mathrm{IHL}_{\mathrm{lib}}+\mathrm{SHL}_{\mathrm{d}} \text {. }
$$

In a hot environment (Fig. 2) it is assumed the pig must reduce $\mathrm{HP}$, through a reduction of feed intake, in order to maintain HP = HPd (Knap, 1999).

WE $(\mathrm{kg} / \mathrm{d})$ is finally obtained assuming a loss of $0.4 \mathrm{~kg}$ water for each MJ heat dissipated as vapour (Blaxter, 1989):

$$
\mathrm{WE}(\mathrm{kg} / \mathrm{d})=0 \cdot 4 \mathrm{IHL}
$$

\section{Water demand for urinary excretion}

When water intake is restricted, the urinary water excretion is calculated as the difference between water intake and the water lost and stored in the body tissues. In such cases the urinary losses will be proportionately reduced until the maximum renal ability to concentrate the urine is reached (for pig about 1 osmol/1; Brooks \& Carpenter, 1990). After that it is assumed that a reduction in feed intake will occur due to the impossibility of the excretion of end products of catabolism (Agricultural Research Council, 1981).

When access to water is free and the feed is not strongly restricted, water consumption is related to the water demand for the urinary excretion. In turn, this depends on the amount of $\mathrm{N}$ compounds and electrolytes that need to be removed through the kidney (Agricultural Research Council, 1981; National Research Council, 1988). In mathematical terms this can be expressed as:

$$
\begin{aligned}
\mathrm{WU}(\mathrm{kg} / \mathrm{d})= & \mathrm{aN}+\mathrm{bS}+\mathrm{cCa}+\mathrm{dP}+\mathrm{eNa}+\mathrm{fCl}+\mathrm{gK} \\
& +\mathrm{hMg},
\end{aligned}
$$

where $\mathrm{a}, \mathrm{b}, \mathrm{c}, \mathrm{d}, \mathrm{e}, \mathrm{f}, \mathrm{g}$ and $\mathrm{h}$ are the water requirements for the renal excretion of 1 osmol each of $\mathrm{N}, \mathrm{S}, \mathrm{Ca}, \mathrm{P}, \mathrm{Na}, \mathrm{Cl}$, $\mathrm{K}$ and $\mathrm{Mg}$ respectively.

The ability of the kidney to concentrate urine has been widely studied in the past on animals of different species (Epstein et al. 1957a,b; Levinsky et al. 1959; Fitzsimons, 1979, Patience \& Chaplin, 1997). Unfortunately the results are not useful in trying to evaluate urinary water requirements when the animal has free access to water and does not consume any antidiuretic substances. The results of Gamble et al. (1929, 1934), in experiments where increasing loads of urea or salts were added to the diets of adult rats and free water consumption was measured, indicated that: (1) '...water requirement for the removal in urine of $n$ osmols of $\mathrm{Na}, \mathrm{Cl}, \mathrm{K}, \mathrm{Ca}, \mathrm{Mg}, \mathrm{P}$ and $\mathrm{S}$, is the same for each of them and, when a mixture of them enter the urine, their requirements are directly additive...'; (2) '...water requirement for the removal of urea in urine is less than the water requirement for the removal of the same number of osmols of $\mathrm{Na}, \mathrm{Cl}, \mathrm{K}, \mathrm{Ca}, \mathrm{P}, \mathrm{S}$ and $\mathrm{Mg}$.'

The equation that we propose in the present paper assumes that the terms are additive. The results of several experiments (Gamble et al. 1934; Epstein et al. 1957a,b; Levinky et al. 1959; Fitzsimons, 1979) do not completely agree with this assumption, because when urea and salts were added to the diet in different proportions, the osmolality of urine was higher than was expected. Not enough information is available, however, to develop a general and simple rule to describe the effect of urea on the total urinary excretion of water. In addition, the equation does not consider the possible hypertonic effect occurring when the animal is forced to eat large amounts of food in a few meals. Further improvements in the functional form of the equation used are needed in order to take into account: (1) the effect of the acid-base balance on renal excretion (Kemme-Kroonsberg, 1993); and (2) the effects of pentosans, such as xylose and arabinose, that might require a lot of water when excreted in the urine (Schutte et al. 1991, 1992).

No useful information has been found to quantify the amounts of water required by pigs for the removal in urine of $\mathrm{N}$ and minerals. Some experiments have been published concerning $\mathrm{NaCl}$ and pig performances (Honeyfield \& Froseth, 1985; Honeyfield et al. 1985) and water 
consumption (Hangsten \& Perry, 1976a,b; Seynaeve et al. 1996; Patience \& Chaplin, 1997), but their data were not suitable. This was mainly because the effect of the dietary $\mathrm{NaCl}$ content on water consumption was also affected by the variable amounts of feed eaten. Other shortcomings in the data, for our purposes, were: the urinary osmotic load, including the contribution of $\mathrm{N}$ and electrolytes, were not provided; the urinary excretion of water was not presented; water was not freely available.

\section{Water requirements for urinary excretion: an experimental contribution}

\section{Material and methods}

To evaluate the effect of the rate of feed consumption, and of the osmotic load, on the urinary excretion of pigs an investigation was performed. Six pigs housed in metabolic cages, were fed, from 40 to $120 \mathrm{~kg}$ body weight, a diet containing $150 \mathrm{~g}$ crude protein/ $\mathrm{kg} \mathrm{DM}$. It had $0.9,1.8,9.5$, 6.0, 5.2, 0.4 and $0 \cdot 3 \mathrm{~g} \mathrm{Na}, \mathrm{Cl}, \mathrm{Ca}, \mathrm{P}, \mathrm{K}, \mathrm{Mg}$ and $\mathrm{S} / \mathrm{kg} \mathrm{DM}$ respectively. A Latin square design was used to divide the pigs into two groups with food freely available for $24 \mathrm{~h} / \mathrm{d}$ (ad libitum) or only for $4 \mathrm{~h} / \mathrm{d}$ (time-restricted). The pigs were adapted to the feeding regimen for $15 \mathrm{~d}$ and the experimental diets were then fed for $42 \mathrm{~d}$. The three pigs in each group alternatively received, in three sub-periods of $14 \mathrm{~d}$, three different levels of $\mathrm{NaCl}(0,15$ and $30 \mathrm{~g} / \mathrm{kg})$ in addition to the feed. Housing temperature was kept between 10 and $15^{\circ} \mathrm{C}$. Feed and water consumption, and urine production, were recorded during the last $10 \mathrm{~d}$ of each experimental sub-period. Samples of urine were collected to be analysed for their osmolality by freezingpoint depression (Hermann Roebling Meßtechnik, Berlin, Germany). The contribution of $\mathrm{N}$ to the total osmolality was assessed by measuring the Kjeldhal $\mathrm{N}$ content of urine (Association of Official Analytical Chemists, 1990) and expressing its value as urea equivalents. The urinary contents of $\mathrm{Ca}, \mathrm{K}, \mathrm{Na}$ and $\mathrm{Mg}$ were measured by means of an atomic absorption spectrophotometer (PerkinElmer 5000; PerkinElmer Instruments, Norwalk, CT, USA) after wet ashing of the samples (Association of Official Analytical Chemists, 1990). P, Cl and S contents were measured using the procedures of the photometric, the mercuric nitrate and the turbidimetric methods respectively described by Association of Official Analytical Chemists (1990)

The GLM procedure of the Statistical Analysis Systems statistical software package, version 6 (SAS Institute Inc., Cary, NC, USA) was run to test the effects of period, feed regimen, group of animal, individual pig (within group), salt level and sub-period on urine osmolality. Period and feed regimen were tested on the group variance and the remaining effects on the residual variance. Regression of the osmotic loads (osmol/d) of $\mathrm{N}\left(x_{\mathrm{N}}\right)$ electrolytes $\left(x_{\mathrm{e}}\right)$ excreted in the urine, with and without an intercept, $v$. the urinary production $(y ; 1 / \mathrm{d})$ was performed, within each method of feed distribution.

\section{Results and discussion}

Urine osmolality was not significantly affected by the experimental periods, the pigs and dietary salt levels, but urine osmolality was significantly higher for the pigs fed $\mathrm{ad}$ libitum compared with those receiving a time-restricted diet ( 0.37 v. 0.26 osmol/1 respectively; SE $0.03 ; \mathrm{P}<0.01)$. The daily osmotic load of $\mathrm{N}$, expressed as urea equivalent, ranged from 0.032 to $1.434 \mathrm{osmol} / \mathrm{d}$ and that of the electrolytes ranged from $0 \cdot 147$ to $1.829 \mathrm{osmol} / \mathrm{d}$.

The relationships between the urinary volume and the osmotic loads are given in Table 3. With $y=$ urinary volume (litres/d), $x_{\mathrm{N}}=\mathrm{N}$ osmotic load (osmol/d) and $x_{\mathrm{e}}=$ mineral osmotic load (osmol/d) the best relationship on feeding ad libitum was $y=2 \cdot 05 x_{\mathrm{n}}+3 \cdot 40 x_{\mathrm{e}}$ (residual SD 1.22 litres/osmol). This suggests a water requirement for the urinary excretion of about 2.05 and 3.40 litres water/ osmol for urea and electrolytes respectively. For the timerestricted feed regimen the intercepts and the slopes were substantially higher. This was likely to reflect the hypertonic effect of a faster rate of food consumption on the amount of water drunk (Houpt \& Anderson, 1990). The standard errors of the slopes, in particular those for $\mathrm{N}$, and the residual variability, were high for both the two feeding regimens. These relationships should be taken as an approximation. In this experiment, only the $\mathrm{NaCl}$ load was changed and the influence of a changed $\mathrm{N}$ load remains to be investigated.

In conclusion, under ordinary feeding conditions WU

Table 3. Relationships, with and without intercept, between the urinary volume $(y, \mathrm{~kg} / \mathrm{d})$ and the urinary osmotic load of nitrogen and minerals (osmol/d), according to different feeding conditions $\dagger$

\begin{tabular}{|c|c|c|c|c|c|c|c|}
\hline \multirow[b]{3}{*}{ Feeding condition $\ddagger$} & & & \multicolumn{4}{|c|}{ Slopes } & \multirow[b]{3}{*}{ RSD } \\
\hline & \multicolumn{2}{|c|}{ Intercept } & \multicolumn{2}{|c|}{ Nitrogen load $\left(x_{n}\right)$} & \multicolumn{2}{|c|}{ Mineral load $\left(x_{\mathrm{e}}\right)$} & \\
\hline & Estimate & SE & Estimate & SE & Estimate & SE & \\
\hline Ad libitum & 0.82 & 0.76 & $\begin{array}{l}1.38 \\
2.05^{\star *}\end{array}$ & $\begin{array}{l}0.99 \\
0.78\end{array}$ & $\begin{array}{l}3 \cdot 20^{\star \star \star} \\
3 \cdot 40^{\star \star \star}\end{array}$ & $\begin{array}{l}0.66 \\
0.63\end{array}$ & $\begin{array}{l}1.21 \\
1.22\end{array}$ \\
\hline Time restricted $(4 \mathrm{~h} / \mathrm{d})$ & 1.65 & 1.00 & $\begin{array}{l}1 \cdot 71^{\star} \\
3 \cdot 31^{\star \star *}\end{array}$ & $\begin{array}{l}1.30 \\
0.90\end{array}$ & $\begin{array}{l}4.08^{\star \star \star} \\
4.68^{\star \star \star}\end{array}$ & $\begin{array}{l}0.83 \\
0.79\end{array}$ & $\begin{array}{l}1.46 \\
1.54\end{array}$ \\
\hline
\end{tabular}

RSD, residual standard deviation.

${ }^{\star} P<0.05,{ }^{\star \star} P<0.01,{ }^{\star \star \star} P<0.001$.

† For details of procedures and mathematical models see p. 874-879.

$\ddagger n 3$ pigs per group. 
can be approximated by the equation:

$$
\begin{aligned}
\mathrm{WU}(\mathrm{kg} / \mathrm{d})= & 2 \cdot 05 \mathrm{~N} / 2+3 \cdot 40(\mathrm{Ca}+\mathrm{P}+\mathrm{Na}+\mathrm{Cl}+\mathrm{K} \\
& +\mathrm{Mg}+\mathrm{S}),
\end{aligned}
$$

where $\mathrm{N} / 2$ is the load of $\mathrm{N}$ excreted, expressed as osmol/d of urea, and $\mathrm{Ca}, \mathrm{P}, \mathrm{Na}, \mathrm{Cl}, \mathrm{K}, \mathrm{Mg}$ and $\mathrm{S}$ are the urinary excretion of each mineral expressed in osmol/d. Under restricted feeding conditions a considerable increase in the urinary loss can be expected.

\section{Evaluation}

The model was evaluated by checking for both mathematical and logical consistency throughout the whole process of development. Preliminary testing can be achieved by comparing the output responses simulated by the model with those measured in the real system. No full comparison can be made without complete details of the experimental conditions that are required as inputs for the model. In addition the model outputs allows us to evaluate the contribution of each single component to the whole response, while the experimental data commonly provide only aggregate measurements, or alternatively only some of the various components of the water balance. Information about the animal, its diet and the environment is required to operate the model. The model was compared using the data from six studies (Holmes \& Mount, 1967; Close et al. 1971; Morrison \& Mount, 1971; Mount et al., 1971; Verstegen et al. 1973; Hangsten \& Perry, 1976a) that reported feed and water consumption of growing pigs kept at various temperatures (from 7 to $33^{\circ} \mathrm{C}$ ). Two data sets from pigs eating $<20 \mathrm{~g} / \mathrm{kg}$ body weight, and one corresponding to a diet containing $<1.1 \mathrm{~g} \mathrm{NaCl} / \mathrm{kg}$, were excluded from the test set. In the test data set there were sixty-eight data points for pigs ranging from 17 to $74 \mathrm{~kg}$ live weight, eating from 0.7 to $3.51 \mathrm{~kg}$ feed/d, receiving variable amounts of minerals and consuming from 2 to 9 litres water/d. Since Holmes \& Mount (1967) and Morrison
\& Mount (1971) did not state the mineral composition of the experimental diets, the proportions of $\mathrm{Ca}, \mathrm{P}, \mathrm{Na}, \mathrm{Cl}, \mathrm{K}$, $\mathrm{Mg}$ and $\mathrm{S}$ in the diet were assumed to be $10 \cdot 0,9 \cdot 0,2 \cdot 0,2 \cdot 0$, $7 \cdot 0,1.3$ and $0.4 \mathrm{~g} / \mathrm{kg} \mathrm{DM}$ respectively. For the experiment of Hangsten \& Perry (1976a) it was assumed that the pigs were kept at $20^{\circ} \mathrm{C}$.

The genotype of the simulated pig was described (Emmans, 1997) by assuming a protein mass at maturity of $35.5 \mathrm{~kg}$, a value of the Gompertz rate parameter B of $0 \cdot 0093 / \mathrm{d}$, a lipid mass:protein mass ratio at maturity of $3 \cdot 0$ and an allometric coefficient of lipid:protein of 1.77 . These values were assumed to correspond to an unimproved pig genotype (Knap, 2000). The simulation was run assuming the following apparent digestibility coefficients as inputs: $0.84,0.77,0.44,0.90,0.60,0.50,0.90,0.85,0.750 .80$ and 0.80 for crude protein, diethyl ether extract, crude fibre, $\mathrm{N}$ free extract, $\mathrm{Ca}, \mathrm{P}, \mathrm{Na}, \mathrm{Cl}, \mathrm{K}, \mathrm{Mg}$ and $\mathrm{S}$ respectively. The biological value of protein was assumed to be $0 \cdot 7$.

The various outputs obtained during the simulation were summarized in terms of mean and variability measurements, and compared with the observed water consumptions. The GLM procedure of the Statistical Analysis Systems statistical software package, version 6 (SAS Institute Inc.) was used to test the differences between the simulated and the observed values of water intake and of the water:feed ratio.

The simulation predicted that urinary excretion and evaporation were the major routes of water loss (Table 4). On average, the urine loss was about 3.30 (SD 1.26) kg/d and the vapour loss was 1.70 (SD 0.89) kg/d. Allowing for the water demand for digestion $(0.11 \mathrm{~kg} / \mathrm{d})$, for faecal excretion $(0.36 \mathrm{~kg} / \mathrm{d})$ and for growth $(0.29 \mathrm{~kg} / \mathrm{d})$, the average total water demand was estimated to be $5.77 \mathrm{~kg} /$ d. As expected, the amounts of water gained from the feed $(0.17 \mathrm{~kg} / \mathrm{d})$, from nutrient oxidation $(0.35 \mathrm{~kg} / \mathrm{d})$ and from the synthesis of body constituents, were all low. The predicted WI was on average 5.15 (SD 1.77) $\mathrm{kg} / \mathrm{d}$ and ranged between 2.37 to $8.45 \mathrm{~kg} / \mathrm{d}$. The predicted water:feed ratio varied between $2 \cdot 20$ and $4 \cdot 86$. The simulated values of the above described variables varied within the ranges

Table 4. Observed and simulated water intakes and other quantities $(\mathrm{kg} / \mathrm{d})$ using experimental data $(n 68)$ on pigs ranging from 17 to $74 \mathrm{~kg}$ of live weight, fed variable amounts of feed (from 0.7 to $3.5 \mathrm{~kg} / \mathrm{d}$ ) and kept at various environmental temperature (from 7 to $33^{\circ} \mathrm{C}$ )

\begin{tabular}{|c|c|c|c|c|c|c|}
\hline & \multicolumn{3}{|c|}{ Observed values } & \multicolumn{3}{|c|}{ Simulated values } \\
\hline & Mean & SD & Range & Mean & SD & Range \\
\hline \multicolumn{7}{|l|}{ Water demand for: } \\
\hline Digestion (WD) & & & & 113 & 34 & $55-200$ \\
\hline Faecal excretion $\left(\mathrm{W}_{\mathrm{fec}}\right)$ & & & & 360 & 112 & $183-672$ \\
\hline Growth (WG) & & & & 294 & 52 & $165-361$ \\
\hline Evaporation (WE) & & & & 1704 & 886 & $641-3992$ \\
\hline Urinary excretion (WU) & & & & 3299 & 1263 & $1314-6508$ \\
\hline \multicolumn{7}{|l|}{ Water input from: } \\
\hline Feed (WF) & & & & 172 & 53 & $78-284$ \\
\hline Oxidation (WO) & & & & 351 & 129 & $165-761$ \\
\hline Synthesis (WS) & & & & 93 & 37 & $13-190$ \\
\hline Drinking (WI) & 4917 & 1876 & $1983-9340$ & $5154 \dagger$ & 1770 & $2368-8454$ \\
\hline Water:feed ratio & $3 \cdot 17$ & 0.91 & $2.05-5.43$ & $3.34 \ddagger$ & 0.69 & $2 \cdot 20-4 \cdot 86$ \\
\hline
\end{tabular}

(Mean values, standard deviations and ranges)

* For details of procedures and mathematical models see p. 874-879.

Simulated values were not significantly different from observed values; $\uparrow P=0.45, \ddagger P=0.23$. 


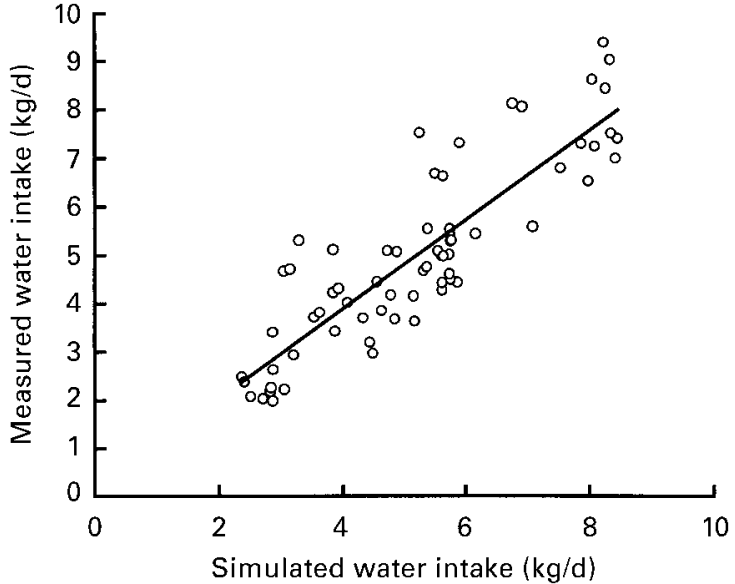

Fig. 3. Measured $(y) \quad v$. simulated $(x)$ values of water intake $\left(y=0.95 x\right.$; residual SE of the slope 0.02 , residual SD $0.92 \mathrm{~kg} / \mathrm{d}, R^{2}$ $0 \cdot 75 ; n 68$ observations). For details of procedures and mathematical models see p. $874-879$.

reported by Agricultural Research Council (1981) and National Research Council (1988). The mean simulated and observed values for water intake and the water:feed ratio did not differ significantly $(P=0.45$ and $P=0.23$ respectively).

The regression of observed WI $(y)$ values $v$. predicted WI $(x)$ values was performed (Fig. 3). The resultant relationship was $y=0.95 x$ (residual SD 0.92 , SE of slope $0.02, R^{2}$ $0.75)$. The value of the slope indicated that overall the model was consistent with the experimental observations, but about $25 \%$ of the variability remained unexplained.

To test if the model was responding in a sensible way to changes in live weight, feed intake and environmental temperature, the measured and the simulated water intakes were also plotted and regressed against each source of variation and the slopes were performed and compared (Figs 4, 5 and 6). As expected, the $R^{2}$ values of all of the

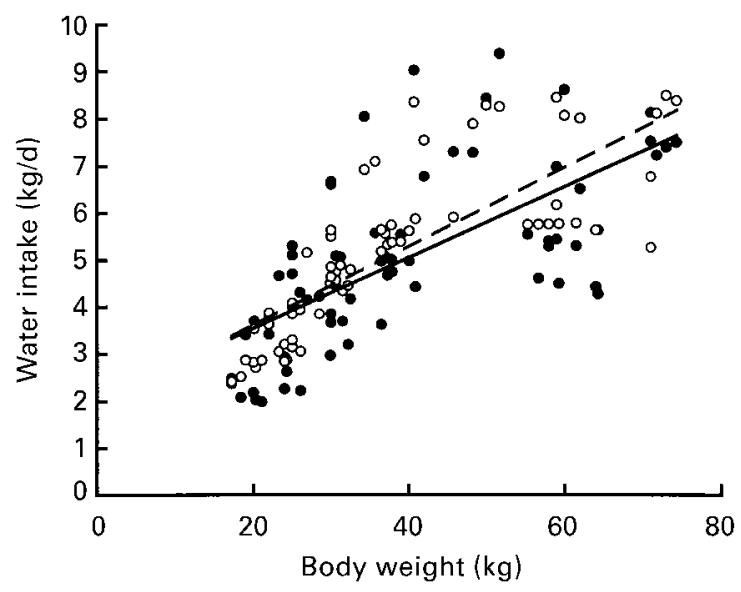

Fig. 4. Effect of body weight on the measured $(\bullet,-)$ and the simulated $(O,----)$ values of water intake ( $n 68$ observations). The regression for the measured values was $y=0.076 x+1.96$ (residual SD $1.40 \mathrm{~kg} / \mathrm{d}, R^{2} 0.45$, SE of the slope 0.010); that of the predicted values was $y=0.084 x+1.87$ (residual SD $1.09 \mathrm{~kg} / \mathrm{d}, R^{2} 0.62$, SE of the slope 0.008 ). For details of procedures and mathematical models see p. 874-879.

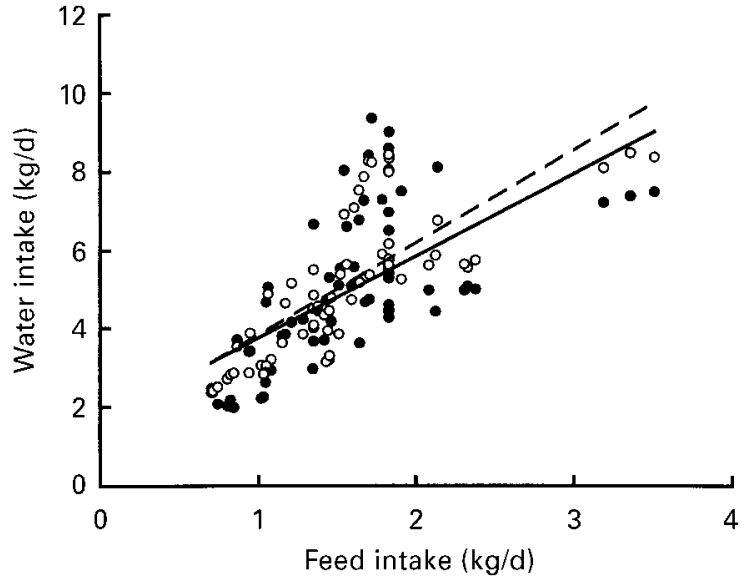

Fig. 5. Effect of feed intake on the measured $(\bullet,-)$ and simulated $(O ;----)$ values of water intake ( $n 68$ observations). The regression for the measured values was $y=2.13 x+1.57$ (residual SD $1.45 \mathrm{~kg} / \mathrm{d}, R^{2} 0.41$, SE of the slope 0.31 ); that of the predicted values was $y=2.39 x+1.40$ (residual SD $1.15 \mathrm{~kg} / \mathrm{d}, R^{2} 0.58$, SE of the slope 0.25 ). For details of procedures and mathematical models see p. 874-879.

equations were low, reflecting the fact that each single source of variation explains little of the whole variability. For the measured and simulated water consumptions the values of the slopes were: 76 (SE 10) and 84 (SE 8) g water/ $\mathrm{kg}$ body weight, 2.13 (SE 0.31) and 2.39 (SE 0.25) kg water/kg feed and $0 \cdot 120$ (SE 0.027) and 0.116 (SE 0.025) $\mathrm{kg}$ water $/{ }^{\circ} \mathrm{C}$ respectively. Since the differences between each pair of slopes were lower than the corresponding standard errors it was concluded that the model was responding in a sensible way to the various sources of variation. This agreement was obtained despite the various simplifying assumptions that were necessarily made in the model.

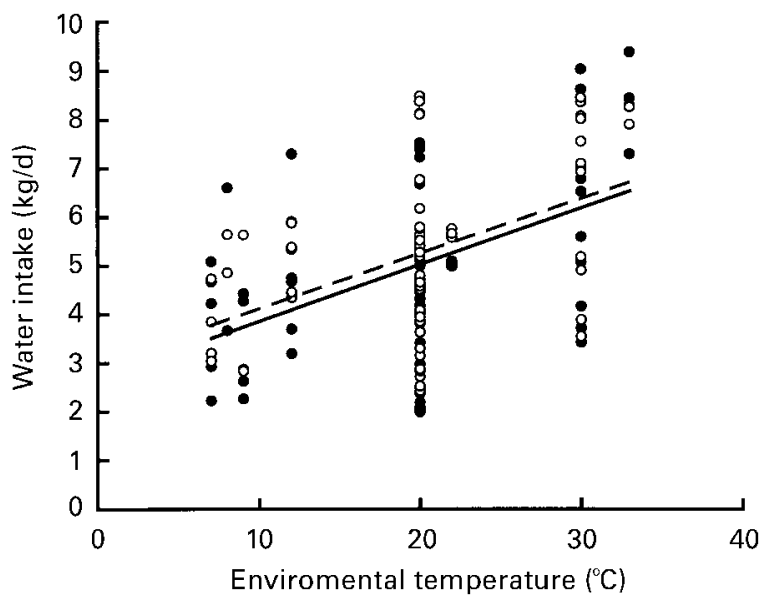

Fig. 6. Effect of the environmental temperature on the measured $(\bullet$, $-)$ and the simulated (O; ---) values of water intake ( $n 68$ observations). The regression for the measured values was $y=$ $0.120 x+2.59$ (residual SD $1.66 \mathrm{~kg} / \mathrm{d}, R^{2} 0.25$, SE of the slope 0.027 ); that of the predicted values was $y=0.116 x+2.90$ (residual SD 1.55, $R^{2} 0.24$, SE of the slope 0.025 ). For details of procedures and mathematical models see p. 874-879. 


\section{Conclusions}

The main purpose of this present work was achieved. Assuming free access to a pure water surface the voluntary water intake of a pig growing on a known diet in a given environment can be predicted using a factorial approach to estimate the amount of water required to meet the different physiological demands. The model is strongly rooted in a theoretical structure in which each step has been developed using experimental data. The pattern and the magnitude of responses to the relevant variables are both sensible. The model allows a good prediction of voluntary water intake and excretion and would seem to be better than other means that are currently available.

Some refinement of the simplified relationships described in this basal model would be desirable. Experiments are needed to quantify water retention by faecal constituents, in particularly of the fibre fractions, and to evaluate the effect of the rate of feed consumption and meal frequency on the amount of water required for the osmotic regulation of the body compartments. A more accurate assessment of the water demand for the urinary excretion of $\mathrm{N}$ compounds and electrolytes, as well as the collection of new information to predict the partition of minerals between faeces and urine, would also be expected to improve the model. Further efforts should consider including in the model the effects of atmospheric humidity and of the temperature of the drinking water on the water demand for thermal regulation. The model can, in principle, be expanded to consider other non-physiological factors. These would include the type and the number of drinkers available in the pen, the water delivery rate, the presence of diuretic or antidiuretic substances in the diet, the health status of the animal and anomalous behaviours such as polydypsia.

\section{Acknowledgements}

The authors wish to thank C. T. Whittemore and many of the staff of the Scottish Agricultural College for their assistance during the development of this work.

\section{References}

Association of Official Analytical Chemists (1990) Official Methods of Analysis, 15th ed., Washington, DC: Association of Official Analytical Chemists.

Appleby MC \& Lawrence AB (1987) Food restriction as cause of stereotypic behaviour in tethered gilts. Animal Production 45, 103-110.

Agricultural Research Council (1981) The Nutrient Requirements of Pigs. Slough: Commonwealth Agricultural Bureaux.

Aarnink AJA, Van Ouwerkerk ENJ \& Verstegen MWA (1992) A mathematical model for estimating the amount and composition of slurry from fattening pigs. Livestock Production Science 31, 133-147.

Black JL (1995) The evolution of animal growth models. In Modelling Growth in the Pig, European Association for Animal Production publication 78, pp. 3-9 [PJ Moughan, MWA Verstegen and MI Visser Reyneveld, editors]. Wageningen: EAAP.

Blaxter KL (1989) Energy Metabolism in Animals and Man, Cambridge: Cambridge University Press.
Blaxter KL, Graham NC, Wainman FW \& Armstrong DG (1959) Environmental temperature, energy metabolism and heat regulation in sheep. II. The partition of heat losses in closely clipped sheep. Journal of Agricultural Science 52, 25-40.

Brooks PH \& Carpenter JL (1990) The water requirement of growing-finishing pigs theoretical and practical considerations. In Recent Advances in Animal Nutrition, pp. 115-136 [W Haresign and DJA Cole, editors]. London: Butterworths.

Close WH \& Mount LE (1978) The effects of plane of nutrition and environmental temperature on the energy metabolism of the growing pig. I Heat loss and critical temperature. British Journal of Nutrition 40, 413-421.

Close WH, Mount LE \& Start IB (1971) The influence of environmental temperature and plane of nutrition on heat losses from groups of growing pigs. Animal Production 13, 285-294.

Cooper PH \& Tyler C (1959a) Some effects of bran and cellulose on the water relationships in the digesta and faeces of pigs. The effects of including bran and two forms of cellulose in otherwise normal rations. Journal of Agricultural Science 52, 332-339.

Cooper PH \& Tyler C (1959b) Some effects of bran and cellulose on the water relationships in the digesta and faeces of pigs. The effect of adding different levels of fibrous cellulose to a highly digestible purified ration. Journal of Agricultural Science 52, 340-347.

Emmans GC (1988) Genetic components of potential and actual growth. In Animal Breeding Opportunities, Occasional Publication no. 12, pp. 153-181 [RB Land, G Bulfield and WG Hill, editors]. Edinburgh: British Society of Animal Production.

Emmans GC (1994) Effective energy: a concept of energy utilization applied across species. British Journal of Nutrition 71, 801-821.

Emmans GC (1997) A method to predict the food intake of domestic animals from birth to maturity as a function of time. Journal of Theoretical Biology 186, 189-199.

Emmans GC \& Fisher C (1986) Problems in nutritional theory. In Nutrient Requirements of Poultry and Nutritional Research, pp. 9-39 [C Fisher and KN Bookman, editors]. London: Butterworths.

Emmans GC \& Kyriazakis I (1997) A general method for predicting the weight of water in the empty bodies of pigs. Animal Science 61, 103-108.

Epstein FH, Kleeman CR \& Hendrinksx A (1957a) The influence of bodily hydration on the renal concentrating process. Journal of Clinical Investigation 195, 629-634.

Epstein FH, Kleeman CR, Pursel S \& Hendrinksx A (1957b) The effect of feeding protein and urea on the renal concentrating process. Journal of Clinical Investigation 195, 635-641.

Ferguson NS, Gous RM \& Emmans GC (1994) Preferred components for the construction of a new simulation model of growth, feed intake and nutrient requirements of growing pigs. South African Journal of Animal Science 24, 10-17.

Fitzsimons JT (1979) The Physiology of Thirst and Sodium Appetite. Cambridge: Cambridge University Press.

Forsum E, Eriksson C, Goranzon H \& Sohlstrom A (1990) Composition of faeces from human subjects consuming diets based on conventional foods containing different kinds and amounts of dietary fibre. British Journal of Nutrition 64, 171186.

Gamble JL, Putnam MC \& McKhann CF (1929) The optimal water requirement in renal function. American Journal of Physiology 88, 571-580.

Gamble JL, McKhann CF, Butler AM \& Tuthill E (1934) An economy of water in renal function referable to urea. American Journal of Physiology 109, 139-154.

Graham H \& Aman P (1991) Nutritional aspects of dietary fibres. Animal Feed Science and Technology 32, 143-158. 
Hangsten IB \& Perry TW (1976a) Evaluation of dietary salt levels for swine. I. Effect on gain, water consumption and efficiency of feed consumption. Journal of Animal Science 42, 11881190.

Hangsten IB \& Perry TW (1976b) Evaluation of dietary salt levels for swine. II. Effect on blood and excretory patterns. Journal of Animal Science 42, 1191-1195.

Holmes CW \& Mount LE (1967) Heat loss from groups of pigs under various conditions of environmental temperature and air movement. Animal Production 9, 435-452.

Honeyfield DC \& Froseth JA (1985) Effects of dietary sodium and chloride on growth, efficiency of feed utilization, plasma electrolytes and plasma basic amino acids in young pigs. Journal of Nutrition 115, 1366-1371.

Honeyfield DC, Froseth JA \& Barke RJ (1985) Dietary sodium chloride levels for growing-finishing pigs. Journal of Animal Science 60, 691-698.

Houpt TR \& Anderson CR (1990) Spontaneous drinking: is it stimulated by hypertonicity or hypovolemia? American Journal of Physiology 258, 143-148.

Kemme-Kroonsberg C (1993) Nutrition and Acid-Base Balance of Pigs: A Review. Rapport IVVO-DLO no. 243, Lelystad: Research Institute for Livestock Feeding and Nutrition.

Klopfenstein C, Bigras Poulin M \& Martineau GP (1996) La truie potomane une realite physiologique (The polydypsic sow, a physiological reality). Journees de la Recherche Porcine en France 28, 319-324.

Knap PW (1999) Simulation of growth in pigs: evaluation of a model to relate thermoregulation to body protein and lipid content and deposition. Animal Science 68, 655-679.

Knap PW (2000) Time trends of Gompertz growth parameters in "meat-type" pigs. Animal Science 70, 39-49.

Kornegay ET \& Graber G (1968) Effect of food intake and moisture content on weight gain, digestibility of diet constituents and N-retention of swine. Journal of Animal Science 27, 1591-1595.

Laitat M, Vandenheede M, Desiron A, Canart B \& Nicks B (1999) Comparison of feeding behaviour and performance of weaned pigs given food in two types of dry feeders with integrated drinkers. Animal Science 68, 35-42.

Levinsky NG, Berliner RW \& Preston AS (1959) The role of urea in the urine concentrating mechanism. Journal of Clinical Investigation 38, 741-747.

Mahan DC \& Shields RG (1998) Macro and micromineral composition of pigs from birth to $145 \mathrm{~kg}$ of body weight. Journal of Animal Science 76, 506-512.

Mitchell HH \& Kelly MAR (1938) Energy requirements of swine and estimates of heat production and gaseous exchange for use in planning the ventilation of hog houses. Journal of Agricultural Research 56, 811-829.

Morrison SR \& Mount LE (1971) Adaptation of growing pigs to changes in environmental temperature. Animal Production 13, 51-57.

Mount LE, Holmes CW, Close WH, Morrison SR \& Start IB (1971) A note on the consumption of water by the growing pig at several environmental temperatures and levels of feeding. Animal Production 13, 561-563.

Mudd AJ, Smith WC \& Armstrong DG (1969) The retention of certain minerals in pigs from birth to $90 \mathrm{~kg}$ of live weight. Journal of Agricultural Science 73, 181-187.

National Research Council (1988) Nutrient Requirements of Swine. Washington, DC: National Academy Press.

National Research Council (1998) Nutrient Requirements of Swine. Washington, DC: National Academy Press.

Patience JF \& Chaplin RK (1997) The relationship among dietary undetermined anion, acid-base balance, and nutrient metabolism in swine. Journal of Animal Science 75, 2445-2452.

Robertshaw D (1981) The environmental physiology of animal production. In Environmental Aspects of Housing for Animal Production, pp. 3-17 [JA Clark, editor]. London: Butterworths.

Robertson JA \& Eastwood MA (1981) An examination of factors which may effect the water holding capacity of dietary fibre. British Journal of Nutrition 45, 83-87.

Schinckel AP (1999) Describing the pig. In A Quantitative Biology of the Pig [I Kyriazakis, editor]. Wallingford: $\mathrm{CAB}$ INTERNATIONAL.

Schutte BJ, De Jong J, Polziehn R \& Verstegen MWA (1991) Nutritional implications of D-xylose in pigs. British Journal of Nutrition 66, 83-93.

Schutte BJ, De Jong J \& Van Weerden EJ (1992) Nutritional implication of L-arabinose in pigs. British Journal of Nutrition 68, 195-207.

Seynaeve M, De Wilde R, Janssens G \& De Smet B (1996) The influence of dietary salt level on water consumption, farrowing and reproductive performance of lactating sow. Journal of Animal Science 74, 1047-1055.

Turner SP, Edwards SA \& Bland VC (1999) The influence of drinker allocation and group size on the drinking behaviour, welfare and production of growing pigs. Animal Science $\mathbf{6 8}$, 617-624.

Van Es AJH (1969) Report to the sub-committee on constant and factors: constant and factors regarding metabolic water. In Proceedings of the 4th Symposium on Energy Metabolism of Farm Animals, European Association for Animal Production Publication no. 12, pp. 513-514 [KL Blaxter, J Kielanowski and $G$ Thorbek, editors]. Newcastle upon Tyne: Oriel Press Limited.

Verstegen MWA, Close WH, Start IB \& Mount LE (1973) The effects of environmental temperature and plane of nutrition on heat loss, energy retention and deposition of protein and fat in groups of growing pigs. British Journal of Nutrition 30, 21-35.

Whittemore CT (1993) The Science and Practice of Pig Production. Essex: Longman Scientific \& Technical. 